\title{
Active versus inactive bacteria: size-dependence in a coastal marine plankton community
}

\author{
Josep M. Gasol ${ }^{1, *}$, Paul A. del Giorgio ${ }^{2}$, Ramon Massana ${ }^{1, * *}$, Carlos M. Duarte ${ }^{3}$ \\ 'Institut de Ciències del Mar, CSIC, Pg. Joan de Borbó s/n, E-08039 Barcelona, Spain \\ ${ }^{2}$ Département des Sciences Biologiques, Université du Québec à Montréal, CP 8888, Succ. A, Montréal, \\ Québec, Canada H3C $3 P 8$ \\ ${ }^{3}$ Centre d'Estudis Avançats, CSIC, Camí de Sta. Bàrbara s/n, E-17300 Blanes, Girona, Spain
}

\begin{abstract}
By directly measuring the size distribution of active (cells that took up and reduced the redox dye CTC, 5-cyano-2,3-ditolyl tetrazolium chloride) and inactive cells in a natural coastal bacterial community, we tested the hypothesis that the likelihood of a bacterium being active in marine plankton is a function of its size. The average size of an inactive bacterium was $0.055 \mu \mathrm{m}^{3}$ while the average size of an active bacterium was $0.12 \mu \mathrm{m}^{3}$. This average size was constant even after $3 \mathrm{~d}$ of incubation in dialysis bags placed in situ, which increased the percentage of active bacteria in the community from 6 to ca $43 \%$. The probability of a bacterium being active was a linear function of its size, from ca $5 \%$ for cells of $0.01 \mathrm{\mu m}^{3}$ to $100 \%$ for cells of the largest sizes. These results (1) support the hypothesis of Stevenson (1978, Microb Ecol 4:127-133) that very small bacteria are mainly dormant (inactive) while bigger bacteria are more likely to be active; (2) reconcile 2 apparently opposing observations, (a) commonly found higher specific activities in the larger size classes of bacterioplankton and (b) allometry regularities by which smaller unicellular organisms tend to have higher specific growth rates than larger organisms of similar metabolic mode; and (3) suggest that phagotrophic protists will preferentially crop the active portion of the bacterial community if they select their prey according to size.
\end{abstract}

KEY WORDS: Bacterial size $\cdot$ Active bacteria $\cdot$ CTC $\cdot$ Bacterioplankton $\cdot$ Size and growth rates

\section{INTRODUCTION}

Free-living planktonic bacteria are important contributors to total community biomass (Cho \& Azam 1990) and activity (e.g. Ducklow \& Carlson 1992). Even though they seem to be preyed upon at high rates (Pace 1988), their numbers are remarkably constant throughout the year. This constancy of bacterial abundance has been hypothesized to derive from a close coupling between bacterial growth and grazing losses (Sanders et al. 1992). However, recent evaluation of this hypothesis has concluded the link between bacterial abundances and those of their main predators

\footnotetext{
-E-mail: pepgasol@masagran.icm.csic.es

- Present address: Biology Department, University of California, Santa Barbara, California 93106, USA
}

(flagellates) to be rather weak (Gasol \& Vaqué 1993). An alternative explanation (Stevenson 1978) is that only a fraction of the total bacterial community is active at a given time, the rest of the cells being dormant (i.e. inactive but able to resume growth if placed in a nutrient-rich environment) or dead (i.e. cells, or parts of cells, that would not resume growth even if placed in the best possible conditions). Evaluations of the size of the non-active bacterial pool suggest that they may represent $>50 \%$, and even $>90 \%$, of the community (e.g. van Es \& Meyer-Reil 1982, Douglas et al. 1987, Pedrós-Alió \& Newell 1989), with a tendency towards comprising a higher proportion in the more oligotrophic systems (del Giorgio \& Scarborough in press).

Novitsky \& Morita (1976) showed that a bacterium isolate placed in mineral medium divided several times without growth to produce many small, inactive but 
viable cells. That evidence led Stevenson (1978) to postulate that the dominance of very small, free-living bacteria typically found in the ocean, which have sizes similar to that of Novitsky \& Morita's isolate, were in a state of dormancy (or lack of activity). Some authors have found empirical evidence for higher growth rates and more individual-specific (and biovolume-specific) production for large bacteria than for smaller bacteria (Bird \& Kalff 1993). These results have been generated studying the uptake of tritiated precursors by different size fractions of the bacterioplankton. Yet, Stevenson's suggestion that very small $\left(<0.07 \mu^{3}\right)$ bacteria are mainly dormant while bigger bacteria are more likely to be active has not been directly tested.

Here, we test such a hypothesis by directly measuring the size distribution of active and inactive cells in a natural coastal bacterial community. We distinguish active cells as those cells that took up and reduced the dye CTC (5-cyano-2,3-ditolyl tetrazolium chloride). We also compute the contribution of each size class to total bacterial production and provide evidence of the size dependence of bacterial specific growth rates.

\section{MATERIALS AND METHODS}

Sampling area and experimental setup. We sampled a natural plankton community in the Bay of Blanes, northwestern Mediterranean $\left(41^{\circ} 39.90^{\prime} \mathrm{N}, 2^{\circ} 48.03^{\prime}\right.$ E) in April 1994. The Bay of Blanes is a shallow, exposed, coastal area with vertically mixed waters. At the time of sampling, chlorophyll a was about $0.3 \mathrm{mg}$ $\mathrm{ml}^{-1}$, nitrate was at very low $(0.2 \mu \mathrm{M})$ concentrations, and phosphate below detection (Mura et al. in press).

The estimates of bacterial production needed to examine the contribution of different size classes to total bacterial production were obtained from the growth rates of bacterial communities enclosed within dialysis bags (SpectraPor) and suspended in situ at $\sim 1.5 \mathrm{~m}$ below surface. The dialysis cultures included a treatment where bacterial growth in water filtered through $0.8 \mu \mathrm{m}$ Nuclepore filters, where predators were absent (del Giorgio et al. unpubl.), was followed. The initial abundance of total and active bacteria and that after $3 \mathrm{~d}$ following growth in situ was quantified in each of triplicated bags

From each bag, $20 \mathrm{ml}$ were set aside for the determination of the number of active cells and 20 more $\mathrm{ml}$ for the determination of bacterial abundance. We identified active bacteria as those where intracellular reduction of CTC to its insoluble fluorescent formazan (also called CTF) derivative occurred. This CTF fluoresces red under green light excitation. The presence of intracellular crystals of CTF is indicative of the presence of an active electron transport system in the cell. In this study, the terms 'active' or 'respiring' bacteria are used as synonymous with CTF-positive bacteria. The redox dye CTC (Polysciences Inc., Warrington, PA, USA) was used following Rodriguez et al. (1992) as modified by del Giorgio \& Scarborough (unpubl.). The samples were incubated with a final CTC concentration of 5 $\mathrm{mM}$ for 10 to $12 \mathrm{~h}$ in the dark and at in situ $\left(14 \pm 1^{\circ} \mathrm{C}\right)$ temperature. Incubations were stopped with the addition of $3 \%$ formaldehyde. DAPI (see below) was then added to counterstain the entire bacterial population. Several different CTC uptake kinetics experiments in planktonic samples of oligo- to mesotrophic lakes suggested $12 \mathrm{~h}$ to be an ideal time span, because the more active bacteria seem to take up and reduce CTC immediately, but the asymptote in the plot of time versus \% CTC-positive cells is reached at $8 \mathrm{~h}$ and does not decline until $>20 \mathrm{~h}$ (del Giorgio \& Scarborough unpubl.). We also used such a long incubation time because cells under nutrient deprivation have been shown to be slower to reduce CTC and to do so with a much lower intensity than non-starved cells (Schaule et al. 1993).

Bacterial abundance and size measurements. Bacteria were preserved with formaldehyde at a final concentration of $3 \% \mathrm{v} / \mathrm{v}$. Subsamples of 5 to $15 \mathrm{ml}$ were stained with DAPI for $2 \mathrm{~min}$ (final conc: $0.1 \mu \mathrm{g} \mathrm{ml} \mathrm{ml}^{-1}$ ) and were filtered onto $0.2 \mu \mathrm{m}$, black-stained Nuclepore filters (Porter \& Feig 1980). Filters were then mounted on a slide with a drop of immersion oil and examined by epifluorescence with a Nikon inverted microscope equipped with a filter set for UV radiation (UV-1A: DM400; Ex 365/10; BA 400) and for green light (G-1B: DM 580; Ex 546/10; BA 590). The images were captured with a Hamamatsu C2400-08 camera equipped with a Silicon-Intensified Target (SIT) and digitized to a Mitsubishi 386 PC using the MIP image analysis program (developed by MICROM España). The final pixel size obtained was $0.067 \mu \mathrm{m}$ pixel $^{-1}$.

Several images were captured for each filter under UV radiation. To determine the size distribution of bacterial cells having CTF deposits, 2 images were captured from each field: one with green light, to detect the red spots due to CTF crystals, and the other with UV radiation, to measure the bacterial size of the corresponding bacteria that had been detected as CTFpositive. Since CTC is not a cellular stain, it does not provide information on the size and shape of the bacteria. It only indicates whether the bacteria had been taking up and reducing CTC. Special attention had to be given to the green light images, since CTF fluorescence faded rapidly.

The images were then downloaded to a Macintosh computer and treated using the public-domain software NIH Image (version 1.55). The aim of image processing was to obtain a binary representation of each 
bacterium. We sequentially applied a Gauss filter (kernel size of $5 \times 5$ ), which reduces the noise of the image, a Laplace filter (kernel size of $5 \times 5$ ), which is a second derivative filter that finds the edges, and a Median filter (kernel size of $3 \times 3$ ) which smooths out the images. That combination of filters has been found to be the best in several trial experiments (Blackburn et al. unpubl.). The resulting images were then visually thresholded to the point where background noise disappears. We previously determined that this process gives results similar to those obtained with the automatic zero-crossing technique described by Sieracki et al. (1989). The area and length of each bacteria were measured automatically by the program. Objects which had an area $<7$ pixels (equivalent diameter $\sim 0.2 \mu \mathrm{m}$ ) were automatically eliminated. Our measurements of bacterial volume are accurate to the third decimal place. To assess the sizes of the bacteria, we measured 300 individual cells for each replicated bag. For active bacteria, much harder to measure because each individual has to be looked for in the filter, we measured 50 to 60 cells per replicate.

Bacterial volume, considering a bacterium as a cylinder with 2 hemispherical ends, was calculated from the area $(A)$ and the length $(L)$ through the intermediate calculation of the equivalent width $\left(W_{\mathrm{e}}\right)$ :

$$
W_{\mathrm{e}}=\frac{2}{(\pi-4)}\left[\left(L^{2}+(\pi-4) A\right)^{\frac{1}{2}}-L\right]
$$

Volume ( $V)$ was then calculated from the following formula:

$$
V=\frac{\pi}{4} W_{e}^{2}\left(L-\frac{W_{e}}{3}\right)
$$

Bacterial volume $\left(\mu \mathrm{m}^{3}\right.$ cell $\left.{ }^{-1}\right)$ times cell concentra-

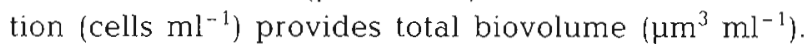
We used the Simon \& Azam (1989) size-dependent volume-to-carbon conversion factor to compute cell mass (pg C cell ${ }^{-1}$ ) from average volume $\left(\mu \mathrm{m}^{3}\right)$. Total biomass ( $B, \mu \mathrm{g} \mathrm{C} \mathrm{ml}^{-1}$ ) was computed as average cell mass times cell concentration. Bacterial production $(P, \mu \mathrm{g} C$ $\mathrm{ml}^{-1} \mathrm{~d}^{-1}$ ) divided by bacterial biomass estimates bacterial biomass turnover rate $\left(T, \mathrm{~d}^{-1}\right)$; specific growth rate $\left(S G R, \mathrm{~d}^{-1}\right)$ was computed as follows:

$$
S G R=\ln \left(1+\frac{P}{B}\right)
$$

Bacterial doubling times ( $D t$, in days) were derived as follows:

$$
D t=\frac{\ln 2}{S G R}
$$

Statistical treatment of the data. Averages were compared with simple $t$-tests. Distributions of bacterial size are usually presented in histograms of arbitrary bin size. We standardized all our size distributions to 21 bins covering from 0.008 to $0.344 \mu^{3}$, which left out some very big cells (in all cases less than 2\%). Bin

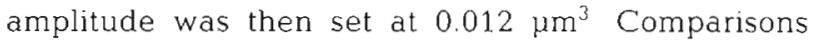
among distributions were done with those size distributions. For some of the computations reported in the discussion, we grouped adjacent bins in pairs (bin size

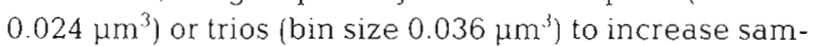
ple size within each bin. Comparisons among distributions were done using Kolmogorov-Smirnov paired sample tests (Young 1977, Conover 1980). In these tests, the null hypothesis is that the 2 samples being compared are samples from the same, continuous, density function.

\section{RESULTS}

In April 1994, the bacterial concentration in the Bay of Blanes was $0.8 \times 10^{6}$ cells $\mathrm{ml}^{-1}$ and only 6 to $7 \%$ were active $(\mathrm{CTF}+)$. Approximately the same values were obtained when we sampled the same assemblage 3 d later. Bacterial concentration inside dialysis bags increased up to $2.0 \times 10^{6}$ cells $\mathrm{ml}^{-1}$ in $3 \mathrm{~d}$, with up to $43 \%\left(0.82 \times 10^{6}\right.$ cells $\left.\mathrm{ml}^{-1}\right)$ being active. Parallel to these changes in bacterial abundances, average bacterial cell size increased from values of ca $0.06 \mu^{3} \mathrm{cell}^{-1}$ in the natural community to around $0.10 \mu^{3} \mathrm{cell}^{-1}$ after $6 \mathrm{~d}$ of incubation. Inactive (CTF-) cells increased from an average size of $0.055 \mu^{3}$ cell $^{-1}$ in the natural community to $0.085 \mathrm{\mu m}^{3} \mathrm{cell}^{-1}$ at the end of the incubation. The population of active $(\mathrm{CTF}+)$ cells always had an average volume larger than the inactive bacterial community: $0.120 \mu^{3}$ as compared to cell sizes of $0.060 \mu^{3}$ for the total population and $0.055 \mu \mathrm{m}^{3}$ for the inactive cell component. Active $(\mathrm{CTF}+)$ cells had the same average size ( $t$-test, $\mathrm{p}<0.005$ ) both in the natural community and at the end of the incubation. The length-to-width ratio $(\mathrm{L}: \mathrm{W})$, descriptor of the dominant bacterial morphology, of the average active cell was $2.51 \pm 0.35$ in comparison to an average $\mathrm{L}: \mathrm{W}$ for inactive cells of $1.66 \pm 0.09$. Thus, active cells tended to be more bacilar than inactive cells, which tended to be more coccoid. The ratio between cell length and width increased with increasing average cell volume for all samples analyzed, even those with active cells, with the exception of the active cells of the in situ assemblage (Fig. 1a). The average cell volume also tended to increase with increasing abundance (Fig. 1b), with a doubling of average bacterial size (from 0.06 to $0.12 \mu \mathrm{m}^{3}$ ) corresponding to a 3 -fold increase (1 $\times 10^{6}$ to $3 \times 10^{6}$ ) in bacterial concentration (Fig. $1 \mathrm{~b}$ ).

Active bacteria made a greater relative contribution to total bacterial biovolume and biomass than to numerical abundance. In the Blanes Bay, $6.4 \%$ of the cells were active but $9.6 \%$ of the biomass and $12.8 \%$ of the biovolume was active. After $3 \mathrm{~d}$ of incubation with- 

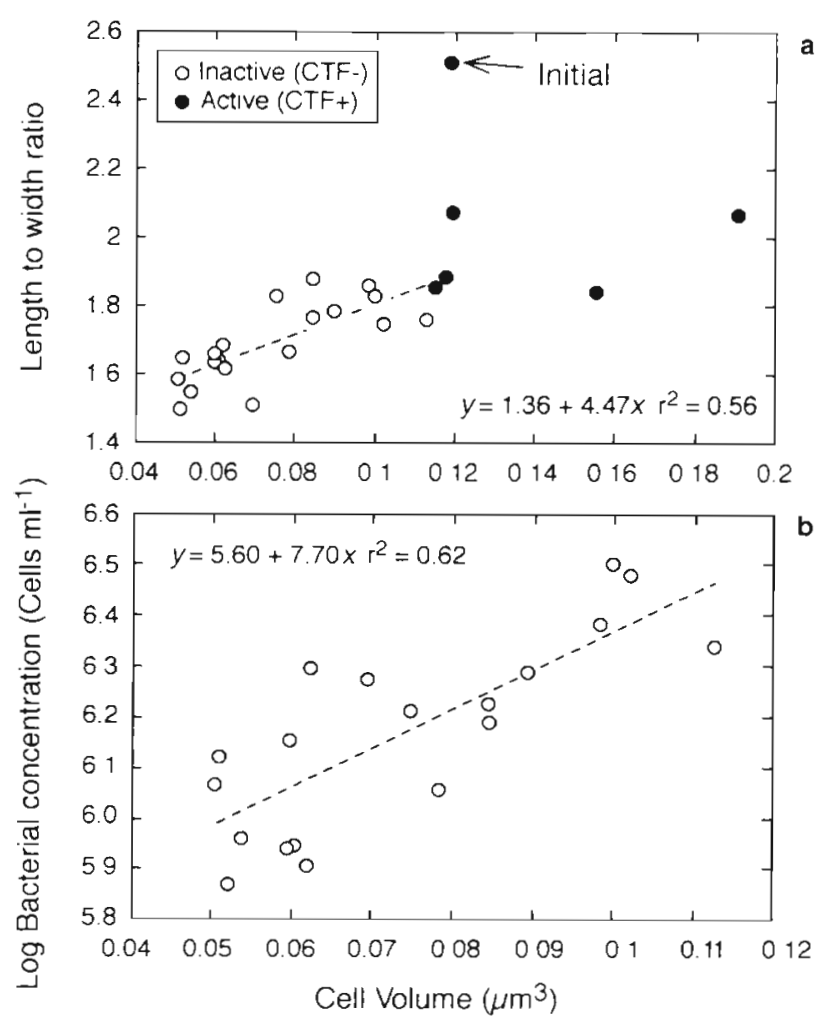

Fig. 1. (a) Correlation between average cell volume and length-to-width ratio for active and inactive bacteria for all different samples analyzed. The equation corresponds to inactive bacteria only. (b) Correlation between average cell volume and cell concentration for total bacteria

out predators, up to $60 \%$ of bacterial biomass and $78 \%$ of the biovolume was active as compared to a contribution of $43 \%$ to cell abundance.

The size distributions of active cells were always significantly different from the size distributions of the corresponding inactive bacterial communities (Fig. 2, $\mathrm{K}-\mathrm{S}$ tests, all $\mathrm{p}<0.05$ ). While the size distribution of active cells in the natural community was not significantly different (K-S tests, $\mathrm{p}>0.05$ ) from the size distributions of active cells at the end of the incubation, most of the total bacteria size distributions at the end of the incubations were significantly different from each other and from the initial distributions.

The maximum number of active bacteria was detected in the size classes with volumes of 0.04 to $0.08 \mu^{3}$ (Fig. 2). The main difference between the size distributions of active and inactive bacteria, both in the natural community but also at the end of the incubation was in the very low abundance of active bacteria within the size classes from 0.008 to $0.04 \mu \mathrm{m}^{3}(0.24$ to $0.48 \mu \mathrm{m}$ of equivalent diameter). Knowledge of the percentage of active cells in each size class, derived from a relatively large sample size, allows the estimation of the likelihood that bacteria within different size
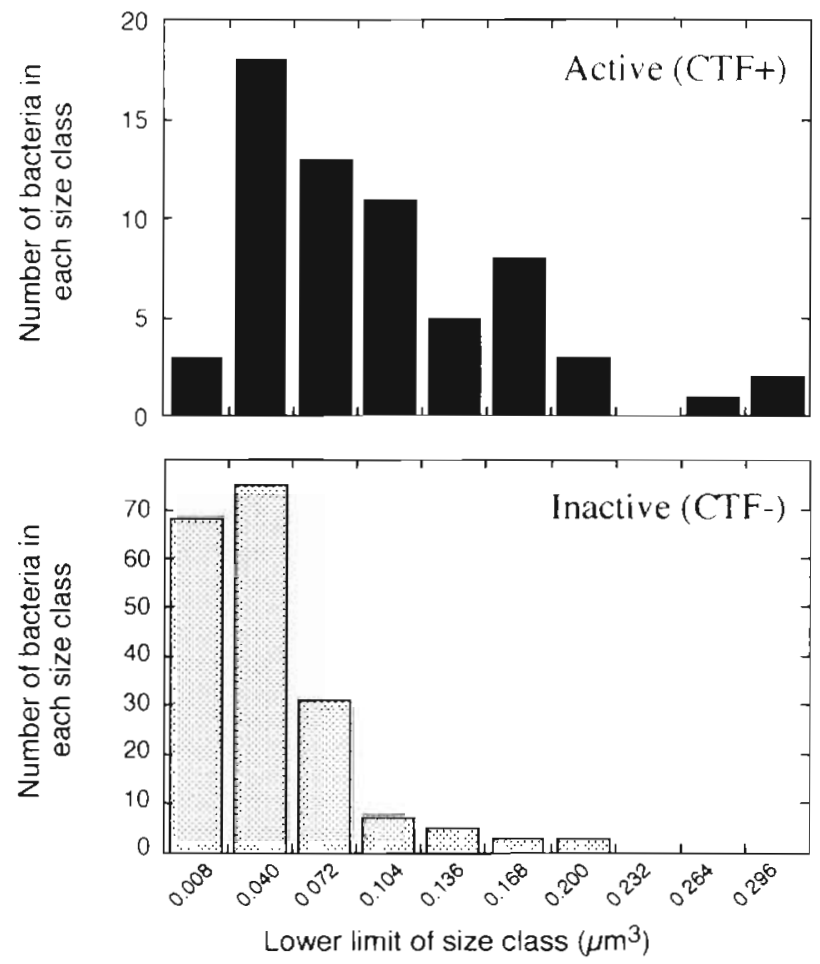

Fig. 2. Size distribution of all active and inactive bacteria measured in this study for the natural community

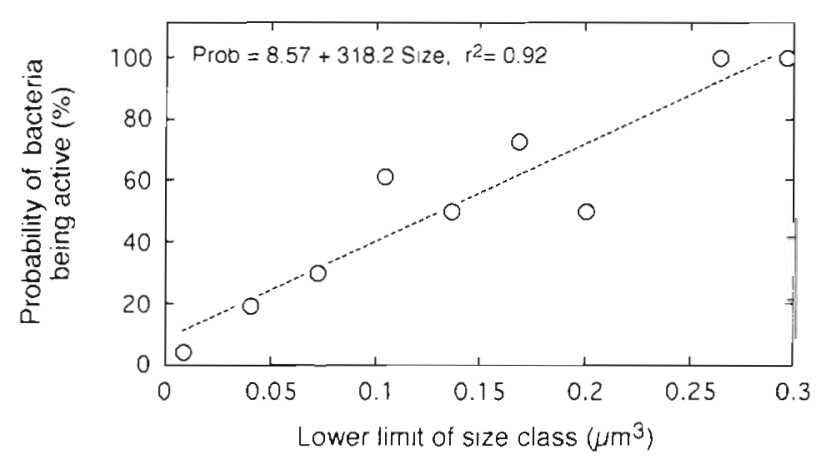

Fig. 3. Probability of bacteria being active as a function of size

classes are active. This probability was strongly sizedependent (Fig. 3), with the probability of a bacterium being active increasing from $8 \%$ in the smaller sizes to $100 \%$ in the largest sizes, and a bacterium of $0.13 \mu \mathrm{m}^{3}$ having a $50 \%$ probability of being active.

\section{DISCUSSION}

Our results demonstrate that, at least for the community studied, active bacteria tended to be larger than non-active bacteria, leading to a strong size-dependence for the probability of a bacterium being active. 
An important implication of this finding is that it lends support to the contention that very small bacteria in the sea may be predominantly 'dormant' or inactive (Stevenson 1978). Indeed, most cells within the smallest size classes $\left(<0.024 \mu^{3}\right)$ did not take up or reduce CTC. Some of the bacteria in the smallest size classes may not be bacteria at all, but rather large viruses (Sieracki et al. 1985, Sieracki \& Viles 1992), which would not take up and reduce CTC. However, by filtering out the particles of equivalent diameter $<0.2 \mu \mathrm{m}$ in the image analysis procedure, we believe that we sized all those particles that an individual would have counted as bacteria under the epifluorescence microscope. Yet there is a need to examine the composition of the pool of cells classified as 'inactive bacteria'.

Some of the small, inactive cells may be in the physiological state referred to as starvation/survival (Morita 1982), in which a metabolic arrest permits the organisms to survive for long periods of time without sufficient energy for growth and reproduction. The generation of 'ultramicrobacteria', 'dwarf cells' or 'minibacteria' (cell length usually $<0.3 \mu \mathrm{m}$, volume $\sim 0.01 \mu^{3}$ ) occurs after several cell divisions without growth under low resource supply. It is generally assumed that this miniaturization benefits the bacterium by providing it with higher surface-to-volume ratios and hence higher ability to scavenge resources, although small size may also facilitate survival by being a refuge from predation (Jürgens \& Güde 1994). However, the dominance of these bacteria in the planktonic environment does not necessarily imply a general nutrient limitation of bacterial growth, and may, instead, derive from a heterogeneous distribution of bacterial resources in space (Azam \& Smith 1991, Duarte \& Vaqué 1992).

Inactive bacteria were present in all size classes, suggesting processes other than miniaturization are also involved. If we assume that most bacteria would tend to reduce in size if the nutrient environment is not adequate, then the presence of large inactive bacteria would support the existence of a very dynamic patchy environment at the scale of the bacteria (cf. Mitchell \& Fuhrman 1989). An alternative possibility is that some large inactive bacteria may have been dead following biotic (viruses, sloppy feeding by predators) or abiotic lysis without loss of the cell structure. These cells are, therefore, 'bacterial ghosts', which we count as DAPIpositive particles, but can neither grow nor divide because they are only cell remnants (Zweifel \& Hagström 1995). In fact, the existence of a strong negative correlation between bacterial loss rates and percent active bacteria in dialysis experiments has been suggested to support this hypothesis (del Giorgio et al. unpubl.).

Several authors have found empirical evidence for higher growth rates and individual-specific (and bio- volume-specific) production for large than for small bacteria (Bird \& Kalff 1993, Båăth 1994). These results were generated by selectively filtering size fractions of the bacterioplankton and studying the uptake of tritiated precursors on each of the size fractions. In those cases, the turnover time of the large size classes was shorter than that of the smallest size classes. These results are in conflict with the general increase in specific production and activity, and reduced generation times, shown by allometric relationships at the smaller end of the size ranges (Fenchel \& Finlay 1983, Peters 1983). However, other authors have reported the expected decline in bacterial growth with increasing size class (Fuhrman 1981, Simon 1988). If many small bacteria were dormant or inactive, as suggested by Stevenson's hypothesis, the above-mentioned contradictory possibilities would reconcile, because activity in the smallest size classes should be scaled to the active biomass (or cell number) only, rather than to the total biomass, to obtain biomass-specific growth rates. A relatively low production, when scaled to a small fraction of the community, could still generate a large biomass-specific growth rate.

Our results allow a comparison of the apparent growth rates in each size class computed from the percentage of active cells in each class, which we have shown to be a function of bacterial size (Fig. 3), and the gross growth rate for active bacteria computed from the change in number of active cells in the incubations and including an estimate for size-dependent bacterial losses (del Giorgio et al. unpubl.). Our calculations of specific growth rates for each of 7 size classes between 0.008 and $0.30{\mu \mathrm{m}^{3}}$ indicated that growth rates increase from ca $0.3 \mathrm{~d}^{-1}$ to $1.4 \mathrm{~d}^{-1}$ and biomass turnover times decrease, with increasing size, (Fig. 4) from $-2.1 \mathrm{~d}$ for small bacteria to $0.5 \mathrm{~d}$ for larger bacteria. This result was clear both for the natural com-

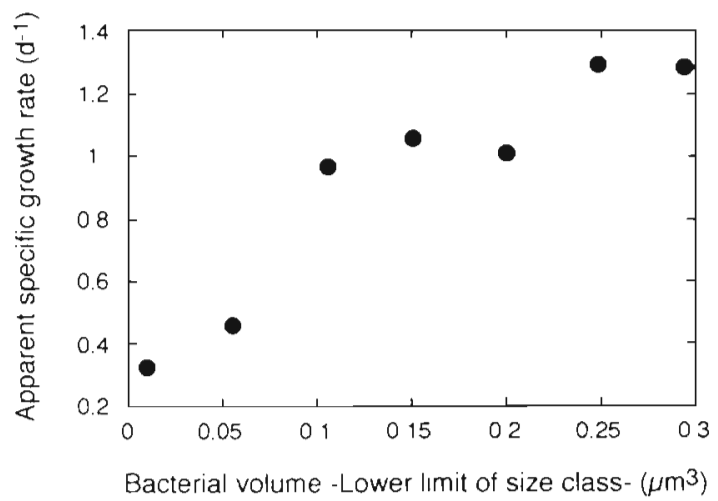

Fig. 4. Changes in apparent specific growth rate for each bacterial size class (see 'Discussion' for description of the assumptions) when bacterial gross growth is scaled to total initial abundance of bacteria instead of being scaled to the active part of the community 

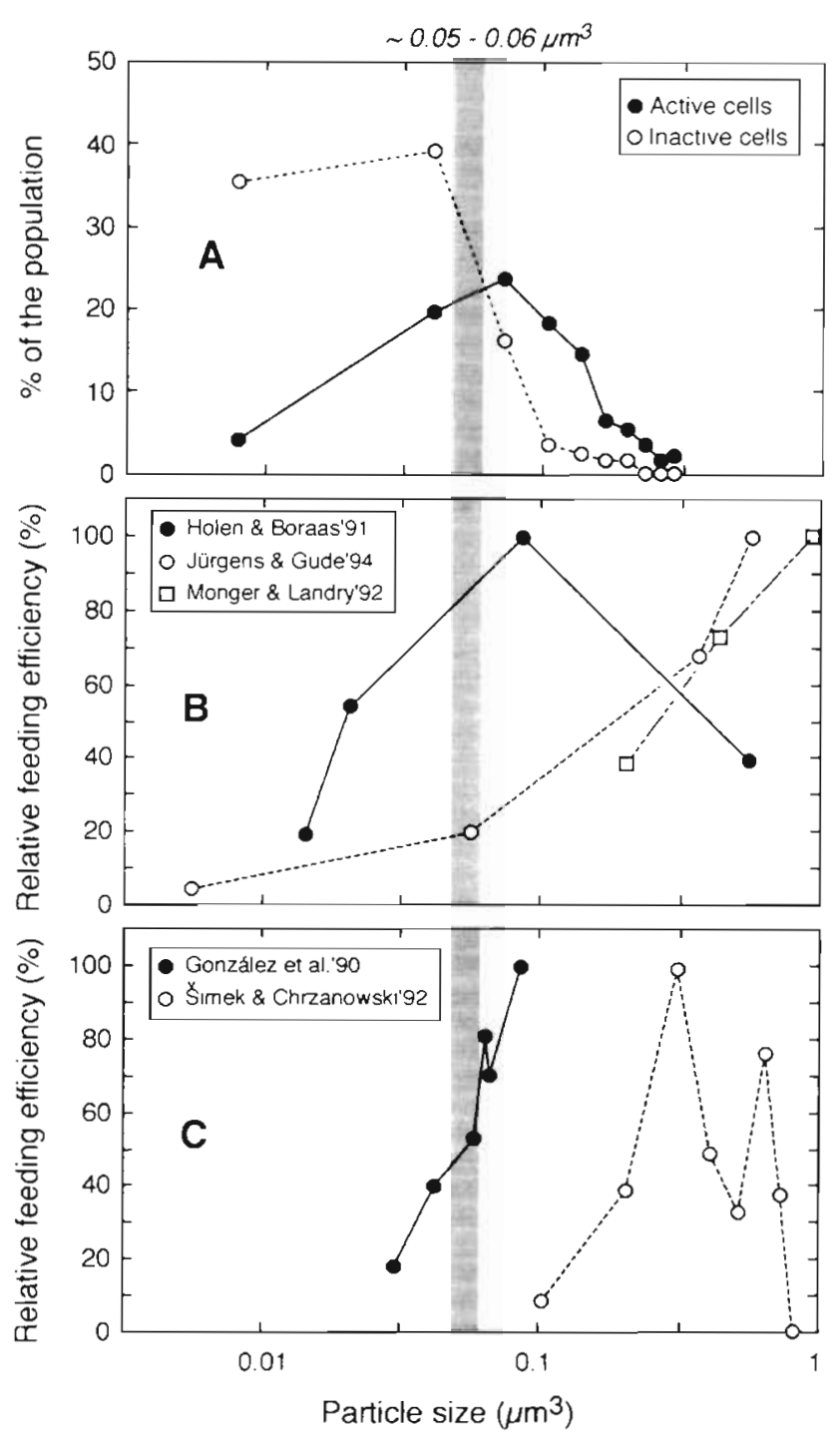

Fig. 5. Modification of the overview graph presented by Jürgens \& Güde (1994) to show how the size distribution of active or inactive cells corresponds to the relative feeding efficiency of protozoans as measured in various studies. (A) Size distribution (as \% of the total population) of active and inactive cells as found in this study (data pooled from all samples). (B) Relative feeding efficiencies ( $\%$ of the maximum) of the nanoflagellate Spumella sp. as reported by Holen \& Boraas (1991) several nanoflagellates species as reported by Monger \& Landry (1992), and Spumella sp. \& Bodo sp. as reported by Jürgens \& Güde (1994). (C) Relative feeding efficiencies ("." of the maximum) of several nano-flagellates and ciliates as reported by González et al. (1990) and several nanoflagellates species as reported by Simek \& Chrzanowski (1992). The area corresponding to bacterial volumes of 0.05 to $0.06 \mu^{3}$ is shaded in all graphs to facilitate interpretation

munity (shown in Fig. 4) and for that obtained at the end of the incubation (not shown). This result explains the findings of Bird \& Kalff (1993) for lake bacterioplankton and Båăth (1994) for soil bacteria, where small bacteria specifically incorporated less precursor per unit of time and bacteria than did larger bacteria. Our results explain those findings and reconcile them with the expected higher growth rates of unicellular organisms of similar metabolic mode (e.g. Peters 1983).

Several empirical studies have shown a preference for larger bacterial prey by cultured and natural assemblages of flagellates (Andersson et al. 1986, González et al. 1990, Holen \& Boraas 1991, Monger \& Landry 1992, Simek \& Chrzanowski 1992, Jürgens \& Güde 1994) and ciliates (Fenchel 1980, Epstein \& Shiaris 1992, Simek et al 1994). In another study, Sherr et al. (1992) showed the preferential removal of dividing cells in systems under flagellate predation. These authors interpreted this as evidence of direct curtailment of bacterial production, rather than bacterial biomass, by bacterial predators, the consequences being smaller bacterial size in the systems with predation and accumulation of small non-dividing cells. Comparison of the relative feeding efficiency of different protists on differentially-sized prey with the size distribution of active and inactive bacteria obtained in the present study (Fig. 5) suggests that protists should feed preferentially (or more efficiently) on the larger size classes, which have a greater fraction of active bacteria. Our results suggest that the reported preferential feeding of protozoans on growing bacteria (Sherr et al. 1992) should also apply to active (respiring) bacteria.

In summary, the strong size dependence of bacterial activity that we have shown has implications for the calculations of bacterial production and for the transfer of carbon in the microbial food web, if inactive bacteria are preyed upon with less efficiency than active and growing bacteria. Our results show the benefits of discriminating within the black box in which all bacteria are usually pooled in attempts to understand the functioning of bacterioplankton communities. We expect that our results will encourage further detailed examination of that conceptual box.

Acknowledgements. We acknowledge the help of Paola Mura, Dolors Vaqué, Susana Agustí and Gistavo Carrera in the sampling and design of the overall experiment. We thank Carlos Pedrós-Alio for the development of the image analysis system and for allowing J.M.G and R.M. to divert some time into this project. This work was supported by research grants AMB94-0746. MAST2-CT93-0077, DGICYT PB91-075. P.A.dG. was supported by an FCAR-GRIL visitung fellowship and the writing of the manuscript was supported by a Québec-Catalunya exchange visit CIRIT grant to J.M.G.

\section{LITERATURE CITED}

Andersson A, Larsson U, Hagström $\AA$ (1986) Size-slective grazing by a microflagellate on pelagic bacteria. Mar Ecol Prog Ser 33:51-57

Azam F, Smith DC (1991) Bacterial influence on the variability in the ocean's biogeochemical state: a mechanıstic view. In: 
Demers $S$ (ed) Particle analysis in oceanography. NATO ASI Ser, Vol G27. Springer-Verlag, Berlin, p 213-236

Båcth $E$ (1994) Thymidine and leucine incorporation in soil bacteria with different cell size. Microb Ecol 27:267-278

Bird DF, Kalff J (1993) Protozoan grazing and the size-activity structure in limnetic bacterial communities. Can J Fish Aquat Sci 50:370-380

Cho BC, Azam F (1990) Blogeochemical significance of bacterial biomass in the ocean's euphotic zone. Mar Ecol Prog Ser 63:253-259

Conover WJ (1980) Practical nonparametric statistics. John Wiley and Sons, New York

del Giorgio PA, Scarborough GA (in press) A comparative study of the number and proportion of metabolically active cells in freshwater and marine bacterioplankton. J Plankton Res

Douglas DJ, Novitsky JA, Fournier RO (1987) Microautoradiograph-based enumeration of bacteria with estimates of thymidine-specific growth and production rates. Mar Ecol Prog Ser 36:91-99

Duarte CM, Vaqué D (1992) Scale dependence of bacterioplankton patchiness. Mar Ecol Prog Ser 84:95-100

Ducklow HW, Carlson CA (1992) Oceanic bacterial production. Adv microb Ecol 12:113-181

Epstein SS, Shiaris MP (1992) Size-selective grazing of coastal bacterioplankton by natural assemblages of pigmented flagellates, colourless flagellates, and ciliates. Microb Ecol 23:211-225

Fenchel T (1980) Suspension feeding in ciliated protozoa: functional response and particle size selection. Microb Ecol 6:1-12

Fenchel T, Finlay BJ (1983) Respiration rates in heterotrophic, free-living protozoa. Microb Ecol 9:99-122

Fuhrman JA (1981) Influence of method on the apparent size distribution of bacterioplankton cells: epifluorescence microscopy compared to scanning electron microscopy. Mar Ecol Prog Ser 5:103-106

Gasol JM, Vaqué D (1993) Lack of coupling between heterotrophic nanoflagellates and bacteria: a general phenomenon across aquatic systems? Limnol Oceanogr 38 $657-665$

González JM, Sherr EB, Sherr BF (1990) Size-selective grazing on bacteria by natural assemblages of estuarine flagellates and ciliates. Appl environ Microbiol 56: 583-589

Holen DA, Boraas ME (1991) The feeding behaviour of Spumella sp as a function of particle size: implications for bacterial size in pelagic systems. Hydrobiologia 220:73-88

Jürgens $K$, Güde $H$ (1994) The potential importance of grazing-resistant bacteria in planktonic systems. Mar Ecol Prog Ser 1.12:169-188

Mitchell JG, Fuhrman JA (1989) Centimeter scale vertical heterogenity in bacteria and chlorophyll a. Mar Ecol Prog Ser 54:141-148

Monger BC. Landry MR (1992) Size-selective grazing by heterotrophic nanoflagellates: an analysis using livestained bacteria and dual-beam flow cytometry. Arch Hydrobiol Beih Ergebn Limnol 37:173-185

Morita RY (1982) Starvation-survival of heterotrophs in the marine environment. Adv microb Ecol 6:171-198

Mura P, Agustí S, del Giorgio PA, Gasol JM, Vaqué D, Duarte CM (in press) Loss-controlled phytoplankton production in nutrient-poor littoral waters of the NW Mediterranean: in situ experimental evidence. Mar Ecol Prog Ser

Novitsky JA, Morita RY (1976) Morphological characteriza- tion of small cells resulting from nutrient starvation of a psychrophilic marine vibrio. Appl environ Microbiol 32: $617-622$

Pace ML (1988) Bacterial mortality and the fate of bacterial production. Hydrobiologia 159:41-49

Pedrós-Alió C, Newell SY (1989) Microautoradiographic study of thymidine uptake in brackish waters around Sapelo Island, Georgia, USA. Mar Ecol Prog Ser 55:83-94

Peters RH (1983) The ecological implications of body size. Cambridge University Press, London

Porter KG, Feig YS (1980) The use of DAPI for identification and enumeration of bacteria and blue-green algae. Limnol Oceanogs 25:943-948

Rodriguez GG, Phipps D, Ishiguro K, Ridgway HF (1992) Use of a fluorescent redox probe for direct visualization of actively respiring bacteria. Appl environ Microbiol 58 $1801-1808$

Sanders RW, Caron DA, Berninger U-G (1992) Relationships between bacteria and heterotrophic nanoplankton in marine and fresh waters: an inter-ecosystem comparison. Mar Ecol Prog Ser 86:1-14

Schaule G, Flemming H-C, Ridgway HF (1993) Use of 5 cyano-2,3-ditolyl tetrazolium chloride for quantifying planktonic and sessile respiring bacteria in drinking water. Appl environ Microbiol 59:3850-3857

Sherr BF, Sherr EB, McDaniel J (1992) Effect of protistan grazing on the frequency of dividing cells in bacterioplankton assemblages. Appl environ Microbiol 58 $2381-2385$

Sieracki ME, Johnson PW, Sieburth JMcN (1985) Detection, enumeration and sizing of planktonic bacteria by imageanalysis epifluorescence microscopy. Appl environ Microbiol 49:799-810

Sieracki ME, Reichenbach SE, Webb KL (1989) Evaluation of automated threshold selection methods for accurately sızing microscopic fluorescent cells by image analysis. Appl environ Microbiol 55:2762-2772

Sieracki ME, Viles CL (1992) Distributions and fluorochromestaining properties of sub-micrometer particles and bacteria in the North Atlantic. Deep Sea Res 39:1919-1929

Simek K, Chrzanowski TH (1992) Direct and indirect evidence of size-selective grazing on pelagic bacteria by freshwater nanoflagellates. Appl environ Microbiol 58: $3715-3720$

Simek K, Vrba J, Hartman P (1994) Size-selective feeding by Cyclidium sp. on bacterioplankton and various sizes of cultured bacteria. FEMS Microb Ecol 14:157-168

Simon M (1988) Growth characteristics of large and small free-living and attached bacteria in Lake Constance. Microb Ecol 15:151-163

Simon M, Azam F (1989) Protein content and protein synthesis rates of planktonic marine bacteria. Mar Ecol Prog Ser 51:201-213

Stevenson LH (1978) A case for bacterial dormancy in aquatic systems. Microb Ecol 4:127-133

van Es FB, Meyer-Reil L-A (1982) Biomass and metabolic activity of heterotrophic marine bacteria. Adv Microb Ecol 6:111-170

Young IT (1977) Proof without prejudice: use of the Kolmogorov-Smirnov test for the analysis of histograms from flow systems and other sources. $J$ Histochem Cytochem 25:935-941

Zweifel UI, Hagström \& (1995) Total counts of marine bacteria include a large fraction of non-nucleoid containing 'ghosts'. Appl environ Microbiol 61:2180-2185 